\title{
6. Local cost of decent housing for a living wage
}

Chapter 5 was concerned with how to establish a standard for acceptable housing for a location. The current chapter is concerned with how to estimate the cost of local housing that meets the local standard.

Estimating the cost of acceptable housing focuses on rent, because it is much easier to collect rental prices than to estimate the cost of home ownership. Many national statistical offices (including the United States) use rent rather than the cost of owner-occupied housing to estimate housing cost when they estimate CPI. Section 6.1 describes how to carry out a local rental cost survey. Section 6.2 indicates how to analyze this information. Section 6.3 discusses the possibility of asking workers about how much they think it would cost to rent acceptable housing in the study location. Sections 6.4-6.5 discuss how to estimate utility costs, fees and routine maintenance and repair costs. In locations where almost all housing is owned rather than rented, finding representative rental costs is difficult. In this case, the user cost of owner-occupied housing is estimated and used as a proxy for rental cost (Section 6.6).

\subsection{Local Rental Cost Survey}

\subsubsection{Locations to visit}

Collection of information on rents should focus on areas where workers typically live. To help locate suitable areas to visit, it is very useful to have a map of the study area that indicates where factories or farms are concentrated as well as where workers typically live. One could start with a published map, or a map downloaded from the web, or a freehand drawn map. Based on discussions with knowledgeable persons, locations of interest such as farms and factories should be marked on the map along with notable roads, towns, landmarks, and markets. In urban areas, key characteristics of neighborhoods should be indicated such as whether they are expensive or unsafe or a slum since slums and unsafe neighborhoods are not acceptable for decent housing and housing in expensive neighborhoods is too costly. ${ }^{1}$ It is also best to avoid neighborhoods that are far away from workplaces and so require an inordinately long commute. Figure 6.1 


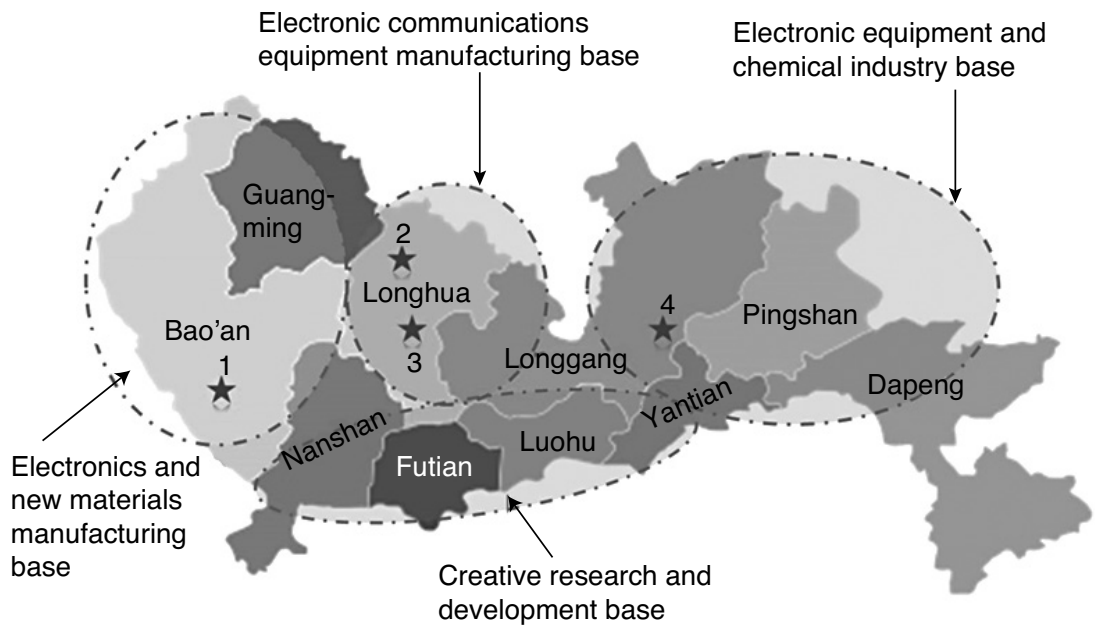

Notes: Stars indicate areas with a concentration of electronics factories. Star 1 represents an area with small electronics factories. Star 2 represents Guanlan Science and Technology Park (in Guanlan town). Star 3 represents Longhua Science and Technology Park (in Longhua Town). Star 4 represents LED lighting and electronic application factories located in Shangrong Science and Technology Industrial Park in Longgang District.

Source: Wang et al. (2016), base map from Wikimedia Commons (https://commons. wikimedia.org/wiki/File:Administrative_Divisions_of_Shenzhen_City.svg).

\section{Figure 6.1 Districts, industrial bases, and study sites, Shenzhen, China}

provides an example of a map of areas in Shenzhen, China that was used for a living wage study that focused on electronics factories in Shenzhen. Notice that factories and the areas where workers live were concentrated in the outskirts of Shenzhen where costs were lower than in the center of the city.

Maps showing the locations of factories sometimes already exist. For example, an interactive map indicating the number of registered and unregistered garment factories in many areas in the greater Dhaka area of Bangladesh is available from the Stern School of Business (Labowitz and Bauman-Pauly, 2015). This map was used to help select areas to collect information on food prices and housing costs for a living wage study that focused on garment factories in Dhaka.

The map used to select locations does not need to be sophisticated. For the Lake Naivasha area of Kenya where a living wage study focused on fresh cut flower farms, we used a hand-drawn map that indicated the main flower farms and the main communities where workers live (Figure 6.2). In other countries, we have asked local key informants to indicate locations 


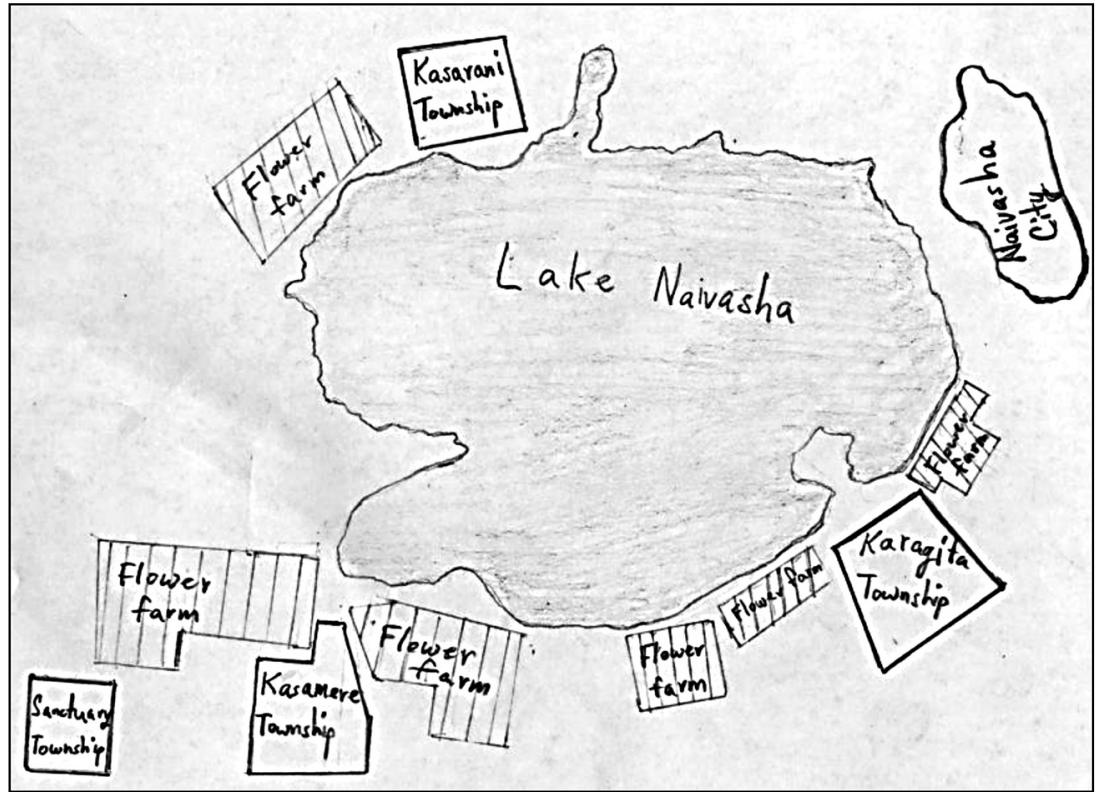

Figure 6.2 Flower farms and townships surrounding Lake Naivasha, Kenya

with the highest concentrations of workers on a road map that we purchased. For agricultural products/industries, we have used a map downloaded from the web of areas in a country where the product of focus is grown that we overlaid with locations of farms to help identify and choose representative study locations.

\subsubsection{Number of neighborhoods to visit}

There is no golden rule as to the number of neighborhoods to visit. This depends partly on time available, heterogeneity of living costs across neighborhoods where workers live, and size of the area covered. For estimating living wages in larger cities, at least three or four different areas should be covered with food and housing costs collected from at least two neighborhoods within each area.

\subsubsection{Finding rental units to visit that meet the local living wage housing standard}

It is often difficult to find basic acceptable rental units to visit, especially when prevailing wages are far below a living wage. In many locations in 
developing countries, workers' housing tends to be substandard because this is all that most workers can afford at present. At the same time, there is usually also a market for housing catering to higher income families that is well above the basic but decent housing standard for a living wage. The market for basic rental units that just meets a living wage housing standard is often relatively small when relatively few workers earn a living wage. This means that efficiency in identifying acceptable rental units to visit is required. Otherwise, an inordinate amount of time would be spent visiting housing below (and often well below) the local living wage housing standard.

We have found that the following approaches increase efficiency:

1. Ask workers about their current housing to identify acceptable housing worth visiting. This can be done individually or in focused group discussions. Workers who live in rented housing that is similar to the living wage local housing standard could be asked if it is OK to visit their homes. We have found it very useful to go with workers to their homes (usually after work, or during work when an employer is willing to excuse workers without reducing their pay). Workers are usually welcoming and other people in the neighborhood are much more willing to let an investigator visit their home when the investigator is accompanied by someone who is known to them. When possible, it is best to arrange to visit houses of several workers who live in a location on the same day to increase efficiency.

2. Visit rented homes of better paid workers such as supervisors and junior management. They are often more likely to be earning a living wage than production workers and so more likely to be able to afford decent housing. It is always necessary to keep in mind that we are interested in the cost of basic but decent housing, no matter who the renter is.

3. When visiting neighborhoods, ask people if they know of other rented homes that have the characteristics of the local living wage housing standard. We have found this to be an effective way of identifying acceptable rental housing.

4. Ask local merchants, such as neighborhood grocery store owners, if they know of rental housing in the location that meets the local housing standard. They are often quite knowledgeable and helpful.

5. Speak to local authorities concerned with affordable rental housing about housing costs. Note that if this information is to be used, such housing must be available to most workers. We found, for example, that low-cost municipal housing in South Africa had a waiting list that was sometimes decades long. 
6. Whether visiting local real estate agents or consulting advertisements in the newspaper is of value depends on the location. In most locations in developing countries, real estate agents and newspapers do not deal with housing of the quality we are interested in. On the other hand, real estate agents were found to be useful in urban China where there is a large rental market for factory workers who share accommodations.

7. On several occasions, we have been able to augment our local market housing survey with data collected by others. In Kenya, we were provided with information from a survey of rental units carried out by the welfare committee of a large farm to help facilitate the transfer of workers from another location.

8. Data on rental costs are sometimes collected and reported by national statistical offices.

9. We have found it useful to ask workers in very co-operative establishments to fill in a questionnaire on the cost (rent, rental value if owned, utilities, fees, taxes) and characteristics of their homes (materials of roof, walls, floor, number of rooms, number of square meters, etc.). This helps identify rental units that meet the local living wage housing standard as well as provides useful information on housing costs. But this type of enquiry is not often possible.

\subsubsection{Usefulness of visiting range of housing above and below local housing standard}

Although we are interested in the cost of renting an acceptable house for a family, it is important to visit a range of dwellings that includes dwellings above and below the local housing standard. This provides a check on the estimated rental cost of acceptable housing, since rent for better and worse housing units bracket rent for acceptable housing units. This is also useful information for explaining to readers the type and the quality of housing workers currently live in.

\subsubsection{Rural-urban differences}

There are usually large differences between rural and urban housing markets and costs. There is often a far greater choice of rentals in urban areas than in rural areas. Indeed, often there is not much of a rental market in rural areas. In addition, acceptable housing standards often differ between rural and urban areas in part because of the higher population density in urban areas.

\subsubsection{Data collection form for rental units}

Table 6.1 is an example of a data collection form that can be used to collect local housing information. Data collected are used in several ways: 
Table 6.1 Example of data collection form for rental units

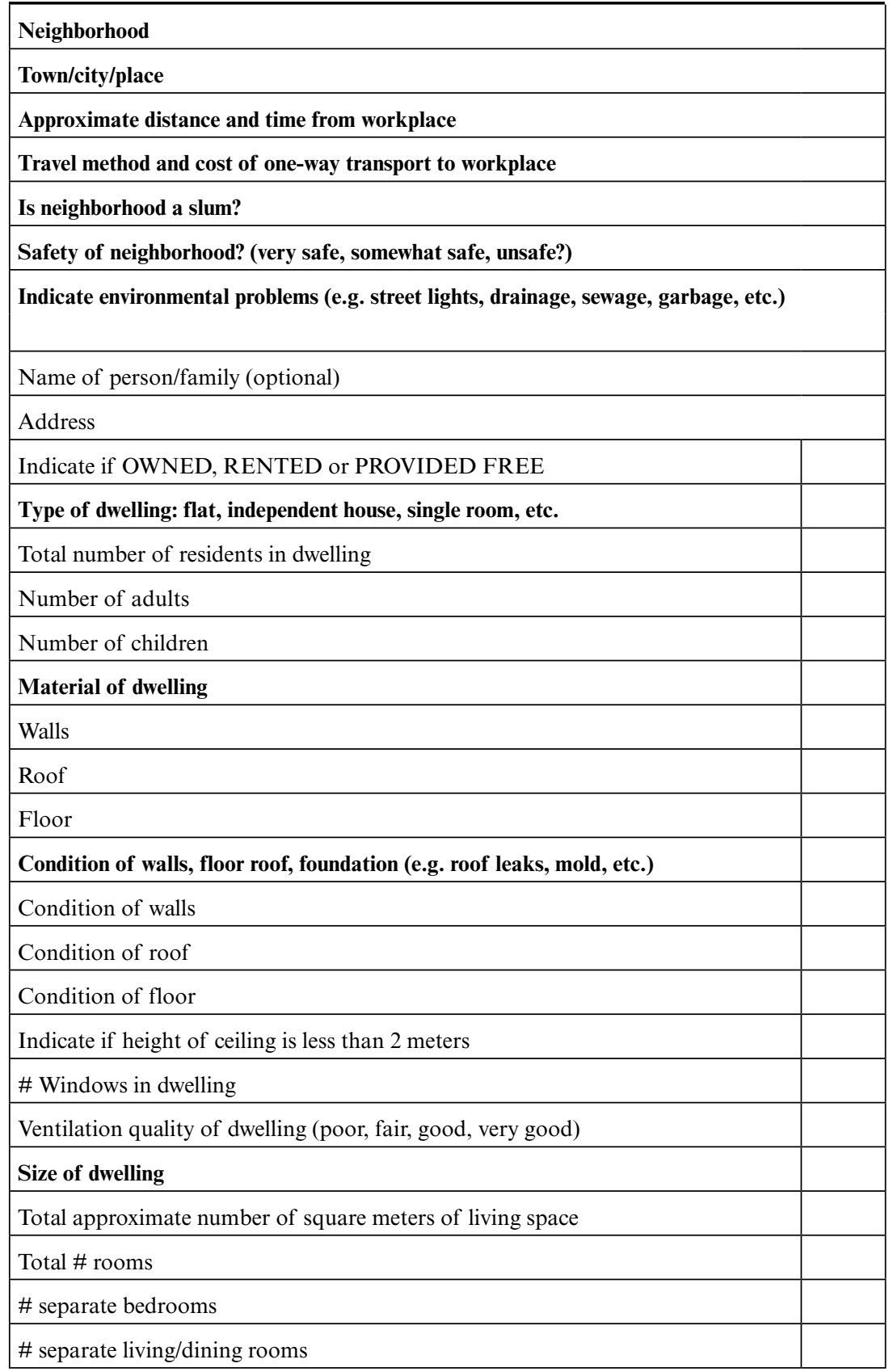




\section{Table 6.1 (continued)}

\begin{tabular}{|c|c|}
\hline If separate kitchen room inside? (yes or no) & \\
\hline If proper ventilation of smoke from cooking? (yes or no) & \\
\hline Is cooking done outside house? (yes or no) & \\
\hline Amenities & \\
\hline Electricity? (hours per day) & \\
\hline Source of water & \\
\hline Separate source of drinking water? If so specify & \\
\hline Piped indoor water? (yes or no) & \\
\hline If no indoor water: distance to water & \\
\hline Number days per week water available & \\
\hline How water stored (e.g. open or closed vessel, tank, jerry can, etc.) & \\
\hline Toilet: pit, flush, or ___? (indicate) & \\
\hline Toilet: inside or outside? (indicate) & \\
\hline Condition of toilet (very good, good, fair, poor) & \\
\hline If toilet fair or poor: Explain e.g. smell, drainage, building condition, etc. & \\
\hline General condition of dwelling (very good, good, fair, poor) & \\
\hline If condition fair or poor: Explain & \\
\hline Consumer durables (yes or no) & \\
\hline Refrigerator & \\
\hline Motorbike & \\
\hline Cost per month (indicate total cost of dwelling even if cost is shared with others) & \\
\hline Rent per month & \\
\hline Electricity cost per month ( 0 if included in rent) & \\
\hline Water cost per month ( 0 if included in rent) & \\
\hline Cooking fuel cost per month ( 0 if included in rent) & \\
\hline Heating fuel: Number of months needed ( 0 if included in rent) & \\
\hline (When used) Cost of heating fuel per month & \\
\hline Other costs per month including fees and taxes (indicate type \& amount) & \\
\hline Investigator's opinion: Does house meet acceptable standards for location? (yes or no) & \\
\hline If no: Indicate reasons why not acceptable & \\
\hline
\end{tabular}


(1) to determine whether or not a dwelling visited meets the local housing standard; (2) to estimate the cost of acceptable housing; and (3) to estimate the cost of utilities such as electricity, water, and cooking fuel, as well as other costs associated with renting a dwelling such as fees and taxes. As with all forms provided in this manual, this form should be adapted to local conditions.

\subsection{Analysis and Presentation of Local Rental Cost Information}

\subsubsection{Table with local rental cost data}

The easiest and most effective way to analyze and present data collected in a local housing survey is to create a table with each housing unit listed in a separate row in ascending order of their rent (see Table 6.2). Variables to describe each housing unit include: (i) whether visited; (ii) whether acceptable and meets or exceeds the local housing standard; (iii) rent per month; (iv) utility costs, fees, and other costs per month; (v) key characteristics such as walls, floor and roof; (vi) size in square meters and number and types of rooms; and (vii) comments. The comments column should indicate reasons why the dwelling was found to be unacceptable or acceptable and what the housing unit was like. Why rent may have been unusually high or unusually low might also be indicated (e.g. landlord was a relative, or rent had not changed in a long time). In this way, the type of housing available at different rents is clearly displayed and it is possible to see what rents are for dwellings below the housing standard, similar to the housing standard, and above the standard.

\subsubsection{Photos of local housing}

We have found it very effective and informative to include photos of local housing in living wage reports - photos of both unacceptable housing and basic acceptable housing. Photos provide a visual perspective and are easy to understand and especially useful for international readers who have little or no familiarity with local conditions. Photos can be especially effective in communicating when many workers currently live in poor housing and the basic nature of the local housing standard.

\subsubsection{Example: Table presenting local rental costs for rural Dominican Republic}

Table 6.2 lists rent from 14 rental units we visited in rural Dominican Republic. We concluded that acceptable housing rented for around RD \$2,000 per month (although one of the lessons we learned from this pilot study is that we should have included more time for fieldwork). Although two acceptable units rented for RD\$1,500, each of these had 
Table 6.2 Cost of rented housing units visited, rural Dominican Republic

\begin{tabular}{|c|c|c|c|}
\hline $\begin{array}{l}\text { Acceptable } \\
\text { standard? }\end{array}$ & $\begin{array}{l}\text { Rent } \\
\text { in local } \\
\text { currency }\end{array}$ & $\begin{array}{l}\text { Size \& } \\
\text { rooms }\end{array}$ & Comments \\
\hline No & 650 & $\begin{array}{l}293 \mathrm{sq} \mathrm{ft} \\
\text { LR, } 2 \text { BR, K }\end{array}$ & $\begin{array}{l}\text { Unsafe neighborhood. Poor condition, } \\
\text { holes in walls and roof. Poor latrine with } \\
\text { wooden platform and seat. }\end{array}$ \\
\hline No & 800 & $\begin{array}{l}224 \mathrm{sq} \mathrm{ft} \\
1 \text { Room }\end{array}$ & $\begin{array}{l}\text { Only } 1 \text { room. No latrine nearby. Had to use } \\
\text { neighbor's latrine. Poor ventilation as only } \\
1 \text { window. }\end{array}$ \\
\hline No & 1,000 & $\begin{array}{l}446 \text { sq ft } \\
\text { LR, } 2 \text { BR, K }\end{array}$ & $\begin{array}{l}\text { Unsafe neighborhood. Outside latrine in very } \\
\text { poor condition despite indoor water. Steals } \\
\text { electricity. }\end{array}$ \\
\hline No & 1,000 & $\begin{array}{l}224 \mathrm{sq} \mathrm{ft} \\
1 \text { Room }\end{array}$ & $\begin{array}{l}\text { Only } 1 \text { room in poor condition with cracked } \\
\text { cement walls, broken cement floor, and leaky } \\
\text { zinc roof. No latrine nearby (uses neighbor's } \\
\text { latrine). In sugar batey (i.e. bateyes are } \\
\text { shantytowns with houses and shops close } \\
\text { to sugar cane fields originally built by sugar } \\
\text { plantations to house sugarcane cutters). }\end{array}$ \\
\hline No & 1,200 & $\begin{array}{l}150 \mathrm{sq} \mathrm{ft} \\
\mathrm{LR}, 2 \mathrm{BR}\end{array}$ & $\begin{array}{l}\text { Tiny rooms. } 14 \mathrm{sq} \mathrm{m} \text {. No kitchen - cooks } \\
\text { outside with charcoal. Shares pit toilet in } \\
\text { very poor condition. No electricity. }\end{array}$ \\
\hline No & 1,300 & $\begin{array}{l}256 \mathrm{sq} \mathrm{ft} \\
\mathrm{LR}, 3 \mathrm{BR}, \mathrm{K}\end{array}$ & $\begin{array}{l}\text { Cement base in poor condition. Latrine in } \\
\text { poor condition. Kitchen roof in poor } \\
\text { condition. Small size as only } 256 \mathrm{sq} \mathrm{ft} \\
\text { living space. }\end{array}$ \\
\hline No & $\begin{array}{l}1,500 \\
\text { (same for } \\
8 \text { years) }\end{array}$ & $\begin{array}{l}391 \mathrm{sq} \mathrm{ft} \\
\text { LR, } 2 \mathrm{BR}, \mathrm{K}\end{array}$ & $\begin{array}{l}\text { Latrine in terrible condition. Damaged roof. } \\
\text { Broken cement floor. Rent unchanged for } \\
\text { eight years. In Mao city. }\end{array}$ \\
\hline No & 1,500 & $\begin{array}{l}420 \mathrm{sq} \mathrm{ft} \\
\mathrm{LR}, 3 \mathrm{BR}, \mathrm{K}\end{array}$ & $\begin{array}{l}\text { Roof leaks. Broken cement base and floor. } \\
\text { Water two days per week. }\end{array}$ \\
\hline No & 1,500 & $\begin{array}{l}410 \mathrm{sq} \mathrm{ft} \\
\mathrm{LR}, 2 \mathrm{BR}, \mathrm{K}\end{array}$ & $\begin{array}{l}\text { Part of house had thatched roof. Roof leaked. } \\
\text { Poor latrine. Wood walls in poor condition. }\end{array}$ \\
\hline Yes & $\begin{array}{l}1,500 \\
\text { (same rent } \\
\text { for } 4 \text { years. } \\
\text { Increase } \\
\text { expected } \\
\text { soon) }\end{array}$ & $\begin{array}{l}365 \text { sq ft }(34 \\
\text { sq m.) } \\
\text { LR, } 2 \\
\text { BR, K }\end{array}$ & $\begin{array}{l}\text { House in fair to good condition. Inside flush } \\
\text { toilet. Rent unchanged for four years, and is } \\
\text { expected to increase soon. }\end{array}$ \\
\hline Yes & $\begin{array}{l}1,500 \\
\text { (same rent } \\
\text { for } 5 \text { years. } \\
\text { Daughter's } \\
\text { godmother } \\
\text { owns } \\
\text { house) }\end{array}$ & $\begin{array}{l}372 \text { sq ft } \\
\text { LR, } 2 \text { BR, K }\end{array}$ & $\begin{array}{l}\text { Cement house in good condition. Outside } \\
\text { latrine in good condition. Outside water } \\
\text { nearby. Rent unchanged for five years. } \\
\text { Landlord is daughter's godmother. }\end{array}$ \\
\hline
\end{tabular}


Table 6.2 (continued)

\begin{tabular}{|c|c|c|c|}
\hline $\begin{array}{l}\text { Acceptable } \\
\text { standard? }\end{array}$ & $\begin{array}{l}\text { Rent } \\
\text { in local } \\
\text { currency }\end{array}$ & $\begin{array}{l}\text { Size \& } \\
\text { rooms }\end{array}$ & Comments \\
\hline No & 2,000 & $\begin{array}{l}299 \text { sq ft } \\
\text { LR, } 2 \text { BR, K, } \\
\text { Bath }\end{array}$ & $\begin{array}{l}\text { Impassible road \& open culvert/sewer in front } \\
\text { of house. Latrine } 30 \text { feet from house, in } \\
\text { poor condition \& shared with four families. } \\
\text { Garbage behind house. }\end{array}$ \\
\hline Yes & 3,000 & $\begin{array}{l}437 \mathrm{sq} f \mathrm{ft} \\
\mathrm{LR}, 2 \mathrm{BR}, \mathrm{K}\end{array}$ & $\begin{array}{l}\text { Very good condition. Indoor water and toilet. } \\
\text { Wood walls, cement base, zinc roof. }\end{array}$ \\
\hline Yes & $\begin{array}{l}4,000 \\
\text { (newly } \\
\text { rented) }\end{array}$ & $\begin{array}{l}370 \text { sq } \mathrm{ft} \\
\mathrm{LR}, 2 \mathrm{BR}, \mathrm{K}\end{array}$ & $\begin{array}{l}\text { Very good condition. Indoor water and toilet. } \\
\text { Wood walls, cement base, zinc roof. Recently } \\
\text { rented. }\end{array}$ \\
\hline
\end{tabular}

Notes: LR indicates living room. BR indicates bedroom. $\mathrm{K}$ indicates kitchen.

a reason for exceptionally low rent (one was rented from a relative; rent for the other was expected to increase soon). Otherwise, we did not find other acceptable units except ones that were much more expensive. Based on this information, we concluded that rent for acceptable housing was above $\mathrm{RD} \$ 1,500$. At the same time, it was clear that $\mathrm{RD} \$ 3,000$ per month was too high, since dwellings well above the local housing standard rented for this amount. In this case, we decided to set rent for basic acceptable housing at a conservative RD $\$ 2,000$ per month. This was on the lower side between the RD $\$ 1,500$ which was known to be too low, and the RD\$3,000 which was known to be too high. This rent was cross-checked with information from banana plantations on the cost of building and maintaining basic acceptable housing for families. It was noted in our living wage report that $\mathrm{RD} \$ 2,000$ per month was approximately two to three times the rent for one small room.

\subsubsection{Estimating rent for an acceptable dwelling using rent per square meter}

Since rent is related to dwelling size, it is possible to estimate rent for an acceptable dwelling from the rent of dwellings of various sizes using observed rent per square meter. Regressing rent (dependent variable) on number of square meters of floor space (independent variable) will indicate whether this relationship is linear or non-linear (such as log linear or quadratic).

Our experience is that the relationship between rent and amount of living space is more or less linear (i.e. cost per square meter is similar regardless of size of dwelling, and so twice as much space costs twice as 
much money) in places where workers rent one bare room without indoor amenities such as piped water, toilet, or kitchen with chimney (see Kenya example below), and non-linear (i.e. cost per square meter falls with size) when even small dwelling units include such amenities because the cost of these amenities is in a sense defrayed over a larger floor space (see Vietnam example below).

This method can provide useful information especially in locations where there are not many rental properties that just meet the local housing standard, but there are many rental properties with required amenities that are too small or too large. Regression results should not be used as a substitute for reported rents in locations where rental properties that are similar to the local housing standard can be found.

6.2.4.1 Example: Using rent per square meter in rental cost estimate for a second tier city in Vietnam Figure 6.3 provides an example of a nonlinear relationship between rent per square meter and house size for houses in a second tier city in Vietnam where most housing has basic amenities of piped water, toilet, and separate kitchen. A log function reasonably represents the relationship between monthly rent (y axis) and size of housing unit in square meters (x axis), with rent per square meter decreasing with house size. Based on this relationship, rent for a housing unit with 36 square meters would cost VND939,637 (VND26,101 per square meter derived from regression multiplied by 36 square meters). Note that if one

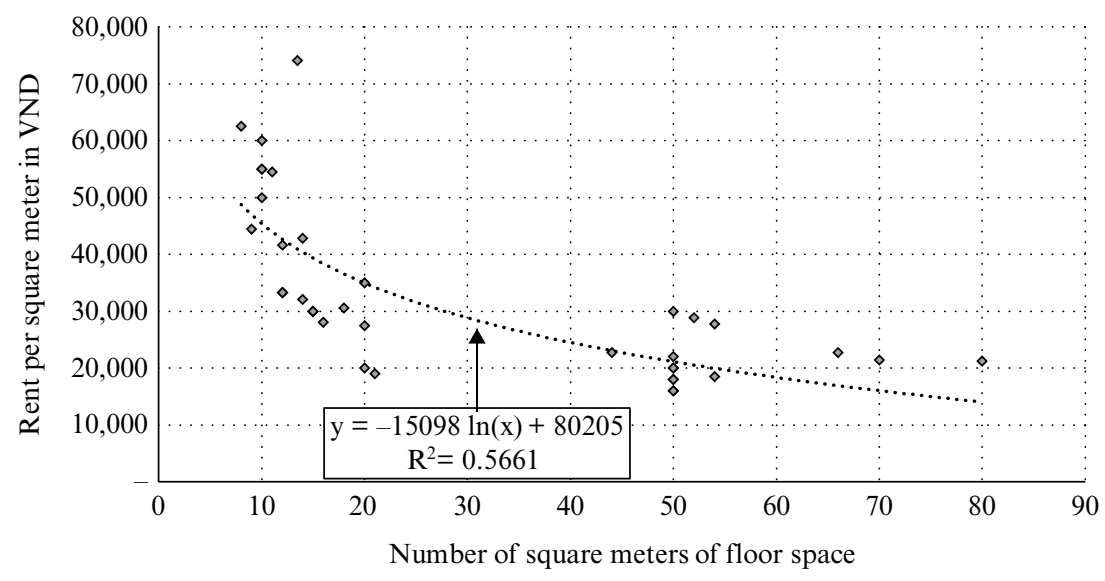

Figure 6.3 Rent per square meter as function of number of square meters for housing that meets all other characteristics of acceptable housing, tier two city in Vietnam 
were interested in rent for units with 50 square meters, there would be no need for regression analysis, because a number of units with 50 square meters were observed.

\subsubsection{Example: Estimate of rental cost in non-metropolitan urban Kenya}

Table 6.3 includes results from our living wage local housing market survey for Lake Naivasha supplemented by a recent survey of available housing done by the workers' welfare committee from a large flower farm. Housing units for most workers consisted of one bare room without kitchen facilities, indoor water, or indoor toilet that was rented by a migrant worker living without his or her family. It was clear that the cost of acceptable housing was more than KSh4,000 per month, since none of the housing units visited with a rent below KSh4,000 were acceptable. At the same time, housing units visited with rent of KSh8,000 or above were more than acceptable. Therefore, rent for basic acceptable housing appeared to be between KSh4,000 and KSh8,000 per month.

To help determine where in the KSh4,000-8,000 range the cost of acceptable basic housing might be, we estimated that rent for the minimum 30-36 square meters required for decency in this location for a family to be around KSh5,400 by extrapolation. KSh5,400 was roughly three times the rent for a 10 feet by 10 feet room (i.e. $3 \times \mathrm{KSh} 1,800$ ) and around 1.5 times rent for two rooms with around 20 square meters of living space (i.e. $1.5 \times$ KSh3,000-4,000). KSh5,400 was felt to be a very conservative estimate of rent for acceptable housing, since while this amount would be enough to rent housing with sufficient space, this space would not include a separate kitchen area with a chimney.

\subsection{Asking Workers How Much They Think Rent is for Housing Similar to the Local Housing Standard}

Statistical offices and researchers sometimes ask people how much they think it would cost to rent housing with particular characteristics. This includes asking home owners how much their house would rent for if it were rented out. In our case, people could be asked how much rent would be for housing that meets the local housing standard. This is a controversial approach to estimating rental costs, because the extent to which people provide reasonable answers varies greatly by country and location, and how questions are asked. Our experience in a number of countries is that this is not a good approach in locations where there is a small rental market for housing that just meets the local living wage housing standard. We have been struck by how variable and often inaccurate people's perceptions of rental costs are in different countries. Statistics South Africa (2008), also 
Table 6.3 Cost of rented housing units visited, Lake Naivasha Kenya

\begin{tabular}{|c|c|c|c|c|c|}
\hline $\begin{array}{l}\text { Acceptable } \\
\text { standard? }\end{array}$ & Source & $\begin{array}{l}\text { No. } \\
\text { rooms }\end{array}$ & $\begin{array}{c}\text { Size } \\
\text { in sq } \\
\mathrm{m}\end{array}$ & $\begin{array}{l}\text { Rent per } \\
\text { month }\end{array}$ & Comments $^{\mathrm{a}}$ \\
\hline No & Visited & 1 & 9 & 400 & $\begin{array}{l}\text { Small. Mud walls. Leaky roof. } \\
\text { No electricity. Poor } \\
\text { ventilation. }\end{array}$ \\
\hline No & $\begin{array}{l}\text { WWC } \\
(24 \\
\text { separate } \\
\text { single } \\
\text { rooms })^{\mathrm{b}}\end{array}$ & 1 & & $\begin{array}{c}\text { Median } \\
1,050 \\
\text { Range } \\
(300-1,500)\end{array}$ & $\begin{array}{l}\text { Single room. } 1 \text { room only. } \\
\text { No electricity. Usually } 10 \\
\text { feet by } 10 \text { feet ( } 9 \text { square } \\
\text { meters) in size. For previous } \\
\text { year. }\end{array}$ \\
\hline No & Visited & 1 & 14 & 1,400 & $\begin{array}{l}\text { Small. Mud walls. Leaky roof. } \\
\text { Poor ventilation. }\end{array}$ \\
\hline No & Visited & 1 & 9 & 1,500 & Small in modern building. \\
\hline No & Visited & 1 & 9 & 1,500 & Small, one room only. \\
\hline No & Visited & 1 & 9 & 1,600 & $\begin{array}{l}\text { Small. Electricity included in } \\
\text { rent, but not allowed to use } \\
\text { electric iron. }\end{array}$ \\
\hline No & $\begin{array}{l}\text { WWC } \\
(36 \\
\text { separate } \\
\text { single } \\
\text { rooms })^{\mathrm{b}}\end{array}$ & 1 & & $\begin{array}{c}\text { Median } \\
1,800 \\
\text { Range } \\
(1,000-2,200)\end{array}$ & $\begin{array}{l}\text { Small, one room only. Usually } \\
10 \text { feet by } 10 \text { feet ( } 9 \text { square } \\
\text { meters) in size. With } \\
\text { electricity. Rents for } \\
\text { previous year. }\end{array}$ \\
\hline No & Visited & 1 & 11 & 2,000 & Small, one room only. \\
\hline No & Visited & 2 & 16 & 2,500 & $\begin{array}{l}\text { Small, two rooms only. In } \\
\text { nearby city. }\end{array}$ \\
\hline No & Visited & 2 & 21 & 2,500 & $\begin{array}{l}\text { Mud walls. Poor ventilation. } \\
\text { No electricity. }\end{array}$ \\
\hline No & Visited & 3 & 29 & 3,000 & $\begin{array}{l}\text { No ventilation. Roof leaked. } \\
\text { In nearby city. }\end{array}$ \\
\hline No & Visited & 2 & 19 & 3,500 & $\begin{array}{l}18 \text { people use one toilet. } 1 / 2 \\
\text { hour walk to bus - } \\
\text { dangerous at night to walk } \\
\text { to home. Poor ventilation for } \\
\text { cooking. In nearby city. }\end{array}$ \\
\hline No & Visited & 2.5 & 21 & 4,000 & $\begin{array}{l}\text { Poor ventilation for cooking. } \\
\text { Too small. }\end{array}$ \\
\hline No & $\begin{array}{l}\text { WWC } \\
(13 \text { two- } \\
\text { room } \\
\text { units })^{b}\end{array}$ & 2 & & $\begin{array}{c}\text { Median } \\
4,000 \\
\text { Range } \\
(1,800-8,000)\end{array}$ & $\begin{array}{l}10 \text { units were KSh } 4,000 \text {; others } \\
\text { were KSh4,500 and } \\
\text { KSh8,000. } 12 \text { of } 13 \text { were in } \\
\text { city. One unit in township } \\
\text { near flower farms was } \\
\text { KSh1,800. Rents for } \\
\text { previous year. }\end{array}$ \\
\hline
\end{tabular}


Table 6.3 (continued)

\begin{tabular}{llcccc}
\hline $\begin{array}{l}\text { Acceptable } \\
\text { standard? }\end{array}$ & Source & $\begin{array}{c}\text { No. } \\
\text { rooms }\end{array}$ & $\begin{array}{c}\text { Size } \\
\text { in sq } \\
\mathrm{m}\end{array}$ & $\begin{array}{c}\text { Rent per } \\
\text { month }\end{array}$ & Comments $^{\mathrm{a}}$ \\
\hline No & Visited & 2 & 19 & 4,000 & $\begin{array}{c}\text { Rooms not connected. To get } \\
\text { to children's room needed } \\
\text { to go through street. Poor } \\
\text { ventilation for cooking. }\end{array}$ \\
Yes & Visited & 4 & 46 & 8,000 & $\begin{array}{c}\text { In nearby city. Separate kitchen } \\
\text { with chimney. Very nice. }\end{array}$ \\
Yes & $\begin{array}{l}\text { WWC } \\
(1 \text { unit) }\end{array}$ & 3 bed & & 12,500 & $\begin{array}{c}\text { In nearby city. Very nice. Rents } \\
\text { for previous year. }\end{array}$ \\
& Visited & 4 & 96 & 15,000 & $\begin{array}{c}\text { In nearby city. Separate kitchen } \\
\text { with chimney. Very nice. }\end{array}$ \\
\hline
\end{tabular}

Notes:

a Unless otherwise indicated, dwellings: (i) were located in urban townships near large flower farms; (ii) did not have indoor water; (iii) water needed to be boiled for drinking; (iv) cooking was done indoors without a chimney using small charcoal stove; and (v) shared pit toilet with concrete slab was of acceptable quality outside house.

b WWC indicates Workers' Welfare Committee of a large farm that looked at available housing in the area in the previous year for management.

found that persons owning a dwelling had 'difficulty' in providing 'a reliable estimate of the market value of their property.' On the other hand, recent living wage studies for cities in Brazil and China, where rental markets are well developed found it useful to ask workers about likely rent for basic acceptable housing (Barbosa et al., 2016, Wang et al., 2016). In short, while this approach can be used, this should be done cautiously and in any case restricted to locations with a well-developed housing market for basic acceptable housing.

\subsection{Utility and Other Housing Costs}

Utility costs and other housing costs such as taxes and user fees are an important part of housing costs. Utility costs include water, electricity, cooking fuel, heat, and lighting.

\subsubsection{Collecting data on utility costs in local housing survey}

To calculate utility costs, it is best to collect information on these costs from several sources in addition to the information collected on a local housing survey, since a local housing survey usually covers a relatively 
small number of houses. In this way, it is possible to estimate utility costs by triangulating between estimates from several sources.

Some utility costs such as water and cooking fuel, increase with family size. To estimate cost per family for water based on data from a local housing survey, it is best to calculate cost per person and multiply this by the reference family size for a living wage. Cost of other utilities, such as heat, electricity, and lighting, which are not as dependent on family size, should be used as reported for the family. Note that when using data on utility costs from a local housing survey, it is necessary to consider the possibility that utility costs indicated by a local housing survey are too low for decency. For example, low wage workers in poor countries might be able to afford only one or two light bulbs and few if any electrical items and for this reason spend very little for electricity; or their landlord might restrict their use of electrical items such as irons that consume a lot of electricity. In these situations, electricity consumption will be below what it would be if a living wage was earned.

\subsubsection{Secondary data on household expenditure for utilities}

Secondary data on the share of household expenditure for utilities from a recent household expenditure survey (or CPI expenditure weights) is a useful source of information. The ratio of the share of household expenditures for utilities to the share of household expenditures for food can be used to estimate utility costs for a living wage by multiplying this ratio by the cost of a living wage model diet. The advantage of these data is that they are based on a large number of households.

\subsubsection{Additional sources of information on utility costs}

1. Discussions with key informants, focus groups discussions with workers, and a questionnaire on housing and utility costs filled out by workers can provide useful information on utility costs.

2. Tax laws can be a potentially useful source when they indicate specific amounts that can be deducted for utilities for income tax purposes. For example, Kenya allows a deduction for electricity of KSh900 for agricultural workers and Ksh1,500 for urban areas (Kenya Revenue Authority, 2009).

3. When water is purchased, the cost for a minimum number of liters of water per person per day required according to WHO (2013) can be used. According to the standards used for emergencies, 20 liters per capita per day is required for drinking and cooking. Minimum water needs increase to 30 liters per day when personal washing is considered and to 40 liters per day when washing clothes is considered. Water for a flush toilet is considerable and in addition. 
4. Drinking water is sometimes purchased separately from water used for other purposes. We have found that even poor households in all of the Dominican Republic and in urban Vietnam purchase bottled drinking water. Drinking water is usually purchased in large plastic jugs. The SPHERE international guidelines for emergencies call for a minimum of 2.5-3 liters of drinking water per person per day depending on climate, physical activity and physiology, and the Institute of Medicine of the National Academies (2004) for the United States indicates that a family of 4 persons (parents and 2 children) needs on average 8.4 liters of drinking water per day (3.0 liters for father, 2.2 liters for mother, and 1.6 liters per child).

\subsubsection{Drawing together different information on utility costs}

Estimates of utility costs from secondary data, a local housing survey, and other sources should be compared. Differences should be examined with reasons for differences considered as the basis for estimating utility costs.

\subsection{Maintenance and Routine Repair Costs}

Every dwelling has expenses for routine maintenance and repairs. How large this cost is for renters depends on responsibilities of renters and landlords for repairs and maintenance, condition of the dwelling, and climate. The cost of improvements should be excluded. Generally, we include nothing or a small amount for renters for repairs and maintenance.

\subsection{User Cost of Owner-occupied Housing as a Proxy for Rental Cost in Locations, such as Rural Areas, Where There is Little or No Rental Market}

Rent for acceptable local housing should be used to estimate housing costs whenever possible based on a local housing survey. This approach is followed because it is difficult and controversial to estimate the cost of housing to home owners and indeed for this reason many national statistical offices use rent to estimate housing costs when estimating CPI.

Unfortunately, this approach may not make sense in locations where not many dwellings are rented. This situation is common in rural areas in developing countries. In such situations, housing cost should be estimated, using what is called the user cost approach.

\subsubsection{How to estimate user cost per month for local housing}

Three approaches (user cost, payment outlays, and acquisition cost) are used by national statistical offices to estimate the cost of owner-occupied 
housing for estimating CPI (ILO et al., 2004). We use the user cost approach to estimate the rental equivalent value of acceptable owneroccupied housing when there is little or no rental market, as does the International Comparison Program (ICP) of the World Bank to determine parity purchasing parity values (PPP) for countries that lack rental market surveys (Heston, 2013).

The following information is needed to estimate the user cost of owneroccupied housing. It is best to obtain this information from several sources as a way of cross-checking the information.

- Cost of constructing a house (or housing unit) that meets the local housing standard.

- Expected service life of a newly constructed house or building. The better the construction and materials, the longer is the expected service life and therefore the lower is annual depreciation cost.

- Cost per year for routine maintenance and repairs. There is a tradeoff between construction cost and annual maintenance costs. The better the construction, the lower are annual maintenance costs.

- Annual taxes, levies, fees, and house insurance.

The following equation is used to calculate the approximate annual user cost of an acceptable owner-occupied dwelling: ${ }^{2}$

Annual user cost of owner-occupied dwelling $=$ Construction cost of new house excluding land cost $\div$ Expected service life of house ${ }^{3}$

+ Annual cost for routine maintenance and repairs ${ }^{4}$

+ Annual taxes, fees, levies, and house insurance 5

It is important to note that the above equation does not include the opportunity cost of money tied up in a house (that could earn income through investments elsewhere) or the capital gains from appreciation of housing prices that are often included in the user cost approach (ILO et al., 2004). This is a controversial aspect of the user cost approach (ILO et al., 2004) and is often excluded in practice (Australian Bureau of Statistics, 2010). There are several reasons why we do not include opportunity cost and capital appreciation of owner-occupied housing to estimate the user cost of owner-occupied housing. First, in locations with little or no rental market (the situation in many rural areas in developing countries), where there are 'limited opportunities for substitution between owner-occupation and renting, it might be argued that the consumption element [of home ownership] dominates' (ILO et al., 2004, p. 184). Second, the opportunity cost of money tied up in a house and capital gain in the value of a house are 
counterbalancing (ILO et al., 2004). Third, houses in rural areas in developing countries are often built with considerable free family labor and the value of this labor cannot be easily put into alternative investments. Fourth, including opportunity cost and capital appreciation in an estimate of user cost would mean that this estimate would be very sensitive to uncertain assumptions (especially in areas without well-functioning housing and capital markets) about interest rates and capital appreciation rates, and this is not a good attribute of an estimation method (ILO et al., 2004).

It is also important to note that the above equation does not include interest costs of a possible mortgage (i.e. total cost of the mortgage minus the principal which is paid back). For example, a $\$ 100,000$ mortgage for 25 years at $6.7 \%$ would consist of around $\$ 200,000$ in total payments, and so around $\$ 100,000$ in interest payments. Ignoring mortgage payments makes sense in locations where most home owners do not take out a bank mortgage to buy or construct their home - which includes most rural areas in developing countries. On the other hand, taking mortgage interest payments into consideration would make sense in locations where there is a well-functioning home loan system and most people buy or build houses using a mortgage from a bank. To get an idea of how important mortgage interest payments might be, we looked at this for Mauritius as part of a living wage study because over $90 \%$ of households in Mauritius own their home (Statistics Mauritius, 2012 Household Budget Survey). We found that approximately $50 \%$ of a home loan consists of interest payments (State Bank of Mauritius home loan calculator, 2016). This increased the user cost of housing by around $40 \%$. Of course, each situation is different, since the importance of mortgage interest payments is significantly affected by the interest rate and number of years of the mortgage, which were $6.69 \%$ and 25 years in this Mauritius example.

\subsubsection{Construction cost of new house or housing unit}

We have obtained information in living wage studies from different sources on the cost of constructing and maintaining low-cost acceptable housing.

1. National, provincial and municipal authorities and officials are often valuable sources, especially departments responsible for increasing the supply of affordable housing. They frequently build and/or financially support housing that meets minimum housing standards. This cost can provide a ball-park figure. We used such information for living wage studies in the Dominican Republic and India.

2. NGOs that build low-cost housing are often a valuable source. This includes prominently Habitat for Humanity that uses local materials to build houses that meet international housing standards. We used 
information on building costs from a local Habitat for Humanity office for living wage studies for Malawi and Kenya.

3. Employers that provide housing for workers are often a good source of information on the cost of constructing and maintaining housing. Such information was used for living wage studies for the Dominican Republic, Malawi, and Sri Lanka. Note that even when housing being built is above a local living wage housing standard, this information can be useful to help provide an upper bound on building costs.

4. Architects and building companies are often able to provide useful information on construction costs. They often use a simple rule of thumb on construction cost per square meter for houses with amenities. We have used this type of information in a number of countries. When discussing housing costs with architects, it is important to remind them of the basic nature of a typical local housing standard for a living wage, because architects are often concerned with higher quality construction.

\subsubsection{Service life of a house}

The expected service life of a house varies across countries and locations depending on materials used, construction quality, climate, and degree of maintenance and repair. 'European countries have generally used service lives of between 50 and 90 years. In the absence of any reliable information, an average service life of 70 years can be used' (OECD and Statistics Norway, 2010, p. 9). Western Balkan countries typically use around 70 years (OECD and Statistics Norway, 2010), and Iceland uses 66.7 years (Diewert, 2010). Habitat for Humanity in Malawi thought that the service life of houses they build was only around 30 years because of the prevalence of termites, high rainfall, and poor construction quality especially for the foundation. Sri Lanka tea estates felt that 50 years was reasonable. We feel that in lieu of other information, an assumption of 50 years of service life is reasonable for basic housing in most developing countries (and up to 70 years of service life in locations where housing quality is similar to housing quality in Europe and the United States).

\subsubsection{Maintenance and repair costs for owner-occupied housing}

We suggest using $2 \%$ for annual cost of maintenance and repairs in lieu of information on this for a study location. Greater or less than $2 \%$ could be used when this is felt to be appropriate for a study location. Data for the United States indicates that around $2 \%$ is a reasonable assumption as American households spend annually around $1.7 \%$ of the value of their house (including land) for maintenance and repairs (Gyourko and Tracy, 2005), and so over $2 \%$ of the value of the building itself considering that 
around one-third of the value of a house is usually for land. Beals (2012) suggests that households in the United States should spend between $1 \%$ and $4 \%$ of the value of a house (and so around $1.5 \%$ to $6 \%$ of the value of the building) on maintenance and repairs.

\subsubsection{Taxes, fees, and levies}

In locations where owners are required to pay taxes, fees, or levies on their home, these should be included in the user cost of owner-occupied dwellings.

\subsubsection{Utility costs}

The monthly cost of utilities such as electricity, lighting, water, gas, etc. is part of housing costs and should be added to the user cost of owneroccupied housing just as it is for rented housing.

\subsubsection{Example of determining user cost of acceptable owner-occupied house: Rural Malawi}

We were not able to find many rental units for our living wage study of rural Malawi. This reflected the setting where only $4 \%$ of rural households rented their homes according to 2010/11 Malawi IHS3 (Republic of Malawi, 2012). For this reason, we followed the user cost approach to estimate local housing costs. We estimated the cost of building a basic acceptable house and used assumptions on service life and maintenance costs.

We obtained information on the cost of building a basic acceptable house from Habitat for Humanity as well as from tea estates that had recently built houses for workers. A local Habitat for Humanity office indicated that a basic house cost K713,000 to construct in 2010. We increased this by the inflation rate since then to get a cost for 2014 of around $\mathrm{K} 1,200,000$. Habitat for Humanity houses had four small rooms with a total of 30 square meters of floor space, zinc roof, cement floor, and burnt brick walls. Windows had wooden frames that did not exactly fit and a tree trunk with multiple curves for the cross beam. These houses were in keeping with Habitat for Humanity principles of building with local materials and ensuring a decent standard considered appropriate for local conditions. Houses being built by tea estates were bigger, more expensive, and better constructed. One tea estate reported K3,209,000 as the cost for a new two unit building (or K1,605,000 per unit). Another tea estate reported K2,300,000 as the cost of a new house. We decided to use the cost of the Habitat for Humanity house as the basis of our estimate of housing costs.

To estimate the user cost of a Habitat for Humanity house, we talked to a Habitat for Humanity engineer and two tea plantation engineers. 
They indicated that the likely service life of a Habitat for Humanity house was around 30 years. This meant that the depreciation cost was $\mathrm{K} 4,333$ per month on a straight-line basis $(1,200,000 / 30 / 12)$. Estimated monthly maintenance costs would be K1,846 using $1.5 \%$ annual maintenance cost, which was slightly below our recommended baseline assumption of $2 \%$ in recognition of the short service life assumption used $(1,200,000 \times .015 / 12)$. Taken together, the estimated user cost was K4,718. Note that this was a very conservative estimate because it was for such a basic house.

\section{NOTES}

1. Many cities have definitions of slums. UN-Habitat (2003a) found that 21 of 30 cities that they looked at had an official definition of slums and 28 of 30 had an unofficial definition.

2. It is not possible to determine rental value directly from a house's value. Data from the United States illustrate how variable this relationship is. The ratio of annual rent to house value for a $\$ 100,000$ house ranged from 0.058 for the Caribbean (Puerto Rico and the US Virgin Islands), to 0.064 for Hawaii and Pacific, 0.082 for Washington DC, and 0.120 for Alaska (Diewert, 2010). Furthermore, this ratio falls with house value, for example going from 0.10 for a $\$ 100,000$ house to 0.033 for a $\$ 900,000$ house in 2004-06 in the United States (Diewert, 2010).

3. This represents depreciation of the housing asset. The cost of the land is ignored, because 'land remains at constant quality for all time' (ILO et al., 2004, p. 184). Land is around one-third of the value of a house in the United States, higher than one-third in Western Europe, and lower than one-third in less densely populated areas of Europe (OECD and Statistics Norway, 2010).

4. 'Expenditures on maintenance and repair are expenditure on repairing parts of a dwelling that are broken or dilapidated; repairing the roof, replacing window frames, painting the outside of a building are examples. Maintenance and repair expenditures do not extend the service life of a building beyond their previously expected lifetimes and do not involve enlarging the dwelling' (OECD and Statistics Norway, 2010, p. 6).

5. The cost of house insurance should be included in locations where it is common, and ignored in locations - most developing countries - where it is not common for workers. The cost of insuring the contents of a house should be subtracted to determine the net house insurance cost. The net cost of home insurance is generally less than $1 \%$ of house value in high income countries (OECD and Statistics Norway, 2010). 